\title{
CORRELATION OF VARIATIONS IN GEOCOSMIC PROCESSES AND THINKING PARAMETERS
}

\author{
Olga D. VolcheK
}

International Science and Research Institute of Cosmoplanetary

Anthropoecology named after the academician V.P. Kaznacheev, Russia

\begin{abstract}
Earlier we discovered gender-specific multiyear variations in functional brain asymmetry (FBA) indices, synergistic with variations in geocosmic processes [Volchek, 2013]. FBA serves as a foundation for different types of learning, perception and processing of information. In its turn, type of learning dominating in society manifests itself in social processes, cultural events and working styles of inventors and artists. The purpose of this work was to study thinking and musical creativity indices in relation to geocosmic processes. With Torrance method, we collected data about logical, intuitive and combined thinking styles in over 3400 citizens of St. Petersburg, Russia, born in 1930-1991. Gender-specific daily, seasonal and multiyear variations in thinking indices were revealed at $p \leq 0.001$. Content analysis of 3352 Soviet songs and romances composed in 1935-1982 showed evolution of musical thinking.

Of special interest is the data on multiyear variations in thinking indices in relation to geocosmic conditions. Significant and reliable variations in thinking types were discovered. For instance, the highest scores for logical thinking type (114.2) were found in men born in 1956, while the lowest scores (82.6) were found in men born in 1959, $p \leq 0.001$. According to the results of correlation analysis for the periods of 1940-1991 and 1946-1991, there are correlations between variations in thinking types and geocosmic indices. The most influential factors are Earth's rotation rate ERR and interplanetary magnetic field IMF. With these indices rising in year of birth and preceding year, scores for left-brain logical thinking type increase, $p \leq 0.001$.

Conclusion: geocosmic processes influence coordination and activation of human brain hemispheres, as well as leading thinking type in society and
\end{abstract}


evolution of music. Such phenomena can be reflected in social processes up to emerge of periods of so-called Thaw or Cold war.

Keywords: cosmic weather; cosmoanthropoecology; thinking types; social and cultural dynamics; social anthropology

\section{INTRODUCTION}

As we know, anthropology in general studies the origins and historical evolution of humans. Fresh prospects are being promised by interdisciplinary approach, engaging findings in the newest branches of anthropology: human ecology, sociocultural anthropology, social psychology, ecopsychology and others. One of the most important problems here is predicting the flow of social processes based on analysis of climate variations. Regarding this, we consider the works by P.A. Sorokin and S.Yu. Maslov about cyclicity of social processes and by A.L. Chizhevskiy and his followers about interrelations between historical trends, human behavior and activity of the Sun $[1,8,16]$ being of highest significance.

There is more and more evidence being accumulated proving that human brain, along with numerous intellectual and psychological functions, is dependent on cosmic environmental conditions and levels of magnetic sensitivity of central control systems [6, p. 157]. It has been discovered that cosmophysical factors affect functional balance of brain hemispheres. For example, rising geomagnetic activity triggers activation of right brain hemisphere and diencephalic structures [7]. Cosmogeophysical conditions during prenatal stage of development have been shown to influence individual's behavioral patterns, intellectual, psychological and anthropological features. The influence is reflected in certain parameters of mental health and cognitive functions $[4,6,20,21]$.

Of great interest is the work by S.Yu. Maslov, devoted to alternating of dominant thinking types (logical and intuitive) and their manifestations in social trends with the periodicity of circa 50 years [8]. According to Maslov's followers V.M. Petrov and O.N. Danilova, when left-brain logical thinking type dominates in a society, it is optimism, enthusiasm, value of knowledge, tendency to open borders and democratic government, looking forward to the future that are prevailing. At times when right-brain intuitive thinking type is dominating, search for life's reason, depression, value of the natural, escapism, separatism and authoritarian tendencies are being intensified [2]. Multiple 
studies have confirmed existence of periods of time favorable or unfavorable for creative activity in various artistic areas and for geniuses and the gifted being born. Although, periodicity of creative activity differed in composers, poets and artists, being asynchronous, and no cycles of approx. 50 years were discovered. Unfortunately, a possibility of correlation between creative activity and cosmic processes was rejected by the authors $[3,11]$.

Previously I have succeeded in tracing the influence of geocosmic conditions onto individual's development and their mental processes, onto indices of thinking and functional brain asymmetry and onto poetic creative activity [20, $22,23]$. The purpose of this work was to review research data on correlations between thinking and cosmic weather with regards to additional information about participants and the factor of Earth's rotation.

\section{RESEARCH METHODS}

The objects of research were citizens of St. Petersburg, Russia, and products of composers' work - pieces of vocal music. The main research methods were epoch counterposition and content analysis. Thinking was studied with Torrance method, which allows to measure functional brain asymmetry for right-brain intuitive (R), left-brain logical (L), dual (F) and mixed thinking types in scores [17]. The content analysis of vocal miniatures was largely targeted at optimism/pessimism index, which is a share of songs in major per year during 1935-1982, Dur, \%. The obtained data was juxtaposed with the values of such well-known indices as interplanetary magnetic field IMF, solar activity (Wolf's spot number) W, geomagnetic activity index Dst, geomagnetic disturbance Kp, neutron flux NF, potential of lunar and solar tide forming force $\mathrm{G}$, deviation of barycenter $\mathrm{BCD}$, Earth's rotation rate $\mathrm{ERR}^{1}$, precipitation, temperature, and others. Mathematical analysis was performed with STATISTICA 7.0 software and included correlation analysis, Fisher criterion $\varphi$ and Student $t$-criterion.

1 Variation in Earth's rotation rate is a weather index, echoed in multiple processes in all geospheres, including biosphere [17]. It is linked to motions of Earth, Moon and Sun. Planetary cycles - particularly, of Jupiter and Saturn, [18] - also manifest themselves in terrestrial weather patterns. Analysis of 3 years of daily weather changes in Moscow and Vladivostok showed that, while current weather values differed, their dynamics was, in most cases, similar [19]. 


\section{RESULTS AND DISCUSSION}

Citizens of St. Petersburg, Russia, born in 1930-1991, were tested with Torrance method. Thinking type values varied from 50 to 180 scores; thinking type with value of 120 scores or more was considered dominant. When total score for indices $\mathrm{R}, \mathrm{L}$ and $\mathrm{F}$ together was less than 120 , the person was considered as having a mixed thinking type.

In the period of 1992-1998, 1601 women and 762 men were tested. Using the epoch superposition method, the obtained results were grouped by three times of day (morning, day and night time). Gender specific diurnal variations of thinking types were discovered. Diurnal variations of thinking types, specific for each gender, were discovered (see Fig. 1). In both genders, logical thinking manifests itself most intensely in the morning and intuitive thinking - in the evening. The diurnal dynamics in thinking is caused by geocosmic variations in luminous density, weather conditions and geomagnetic field due to Earth's rotation around its axis.
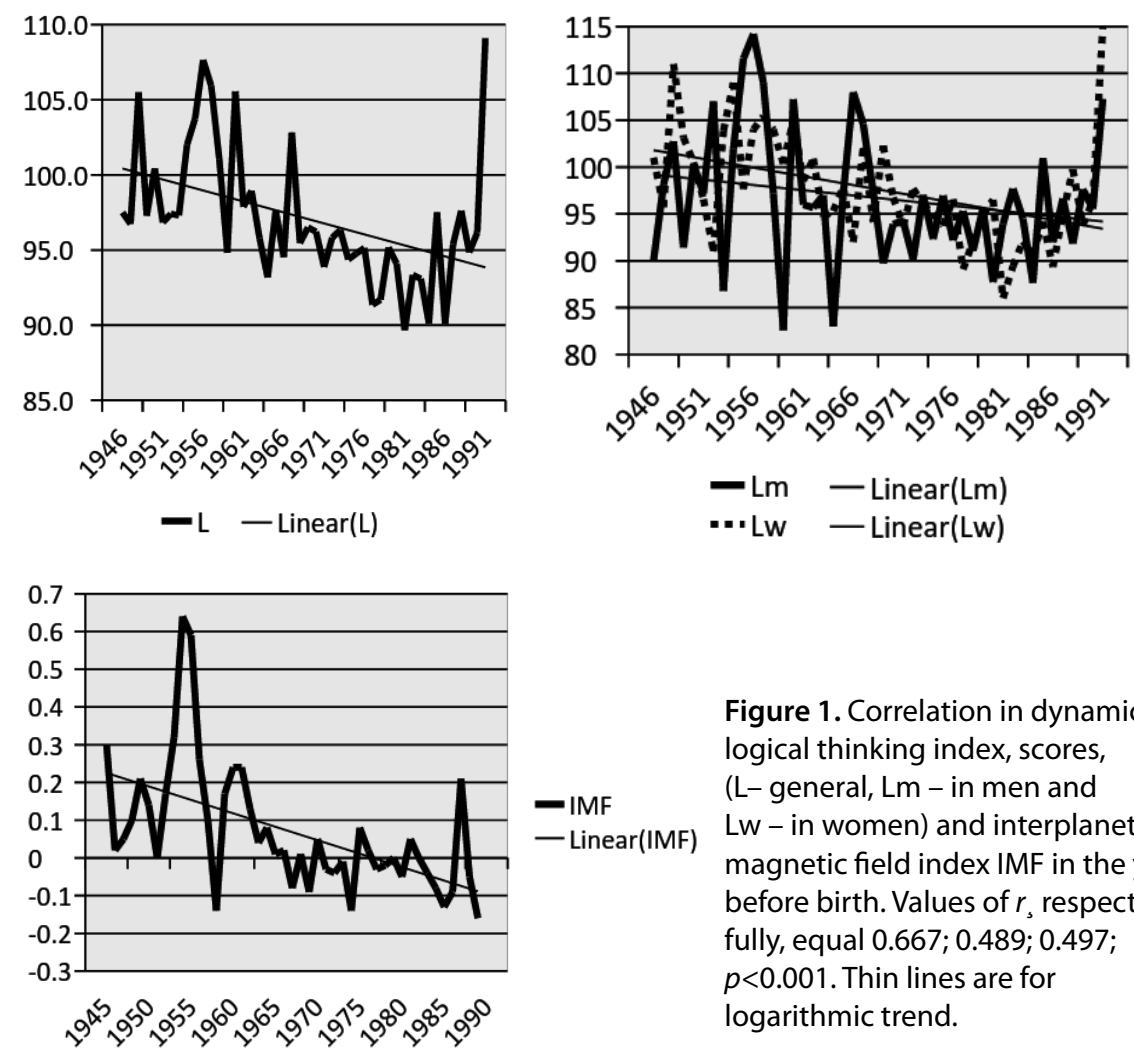

Figure 1. Correlation in dynamics of logical thinking index, scores, ( $\mathrm{L}$ - general, $\mathrm{Lm}$ - in men and Lw - in women) and interplanetary magnetic field index IMF in the year before birth. Values of $r_{s}$ respectfully, equal $0.667 ; 0.489 ; 0.497$; $p<0.001$. Thin lines are for logarithmic trend. 
Similarly, seasonal and yearly average values for the period of 1992-2003 were calculated, as well as by year of birth of participants. Information about 2315 women and 1096 men born 1912-1991 was collected and processed, with the most representative sample being people born in 1946-1991.

It was discovered that values of thinking indices significantly and reliably varied by season of testing and by participants' year of birth. For instance, average logical thinking scores varied in men from 82.6 (born in 1959) to 114.2 (born in 1956) and in women from 81.2 (born in 1944) to 115.5 (born in 1991). Average intuitive thinking scores varied in men from 82.0 (born in 1948) to 114.9 (born in 1984) and in women from 89.7 (born in 1954) to 126.7 (born in 1952). As for dual thinking type, average scores in men varied from 88.8 (born in 1965) to 119.2 (born in 1949); average scores in women varied from 91.7 (born in 1960) to 111.7 (born in 1951), $p \leq 0.001$.

Correlations between thinking indices and geocosmic indices in year of birth and preceding year were analyzed: the results are shown in Fig. 1, 2, 3, 4. As can be seen, the leading factors are ERR and IMF. Their growing in year of birth and preceding year is accompanied with intensifying of left-brain logical thinking in both men and women.

Analysis of Fig. 2, 3 and 4 shows significant gender-specific differences in both multiyear dynamics of thinking parameters and respectful correlation pleiades. For instance, fluctuations of $\mathrm{L}$ index in men and women are nonsynchronous, at times shifted by a year or mirrored, although general trend is preserved.

The correlation pleiades share some similar features, such as major influence of indices IMF and ERR and a negative correlation between intuitive thinking and IMF. As for differences between men's and women's correlation pleiades, it can be seen that the logical thinking index $\mathrm{L}$ in women has stronger correlation to indices IMF and ERR than in men, while the intuitive thinking index $\mathrm{R}$ in men appears to have three more correlations, undetected in women: negative ones with the neutron flux index NF and the geomagnetic activity index Dst in year of birth and a positive one with the temperature index. Moreover, the dual thinking index $\mathrm{F}$ in men demonstrates a positive correlation with the neutron flux index NF in year of birth and a negative correlation with the temperature index in the preceding year, while the same index $F$ in women appears to have only one negative correlation with the geomagnetic disturbance index Kp.

If we look at the year before birth, there are some highly interesting facts: in both genders, intuitive thinking positively correlates with the precipita- 


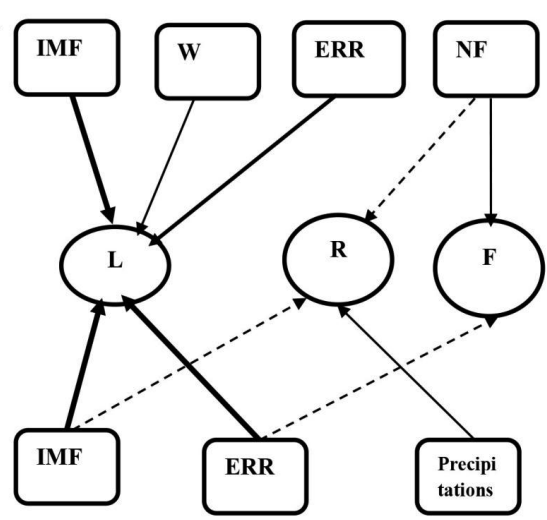

Figure 2. Correlational pleiadas for logical thinking index $L$, intuitive thinking index $\mathrm{R}$ and dual thinking index $\mathrm{F}$ in people born 1946-1991, non-gender-specific.

Top - year of birth, bottom - preceding year. Keys: IMF - interplanetary magnetic field, ERR - Earth's rotation rate, $\mathrm{W}$ - solar activity, $\mathrm{NF}$ - neutron flux.

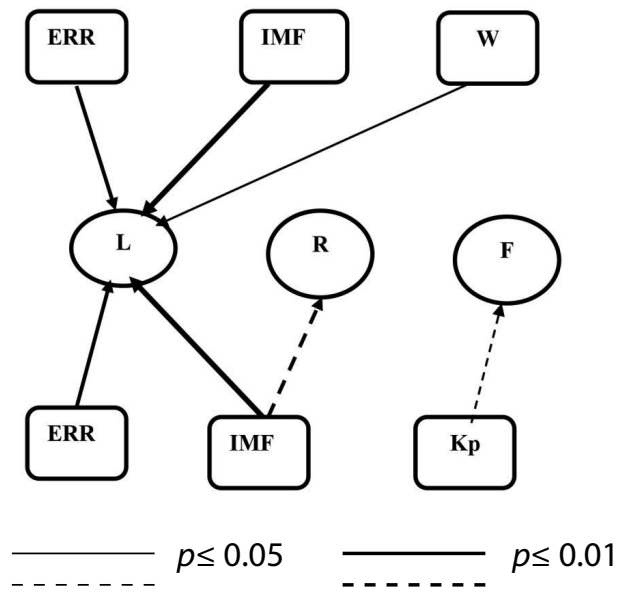

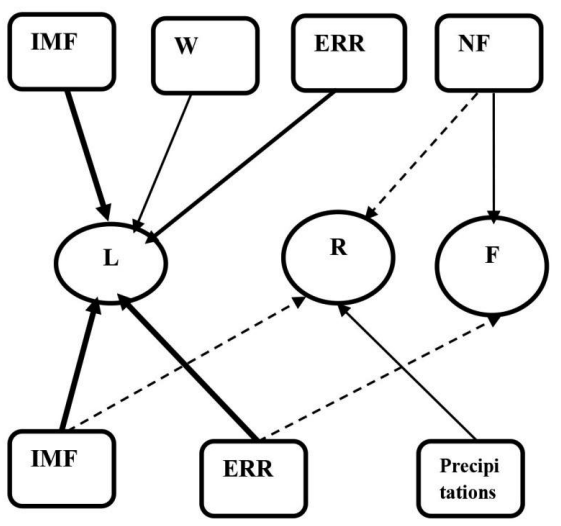

Figure 3. Correlational pleiadas for thinking indices $L, R$ and $F$ in men born 1946-1991. Top - year of birth, bottom preceding year. Keys: IMF - interplanetary magnetic field, ERR - Earth's rotation rate, NF - neutron flux, Dst - geomagnetic activity.

Figure 4. Correlational pleiadas for thinking indices $L, R$ and $F$ in women born 1946-1991. Top - year of birth, bottom preceding year. Keys: ERR - Earth's rotation rate, IMF - interplanetary magnetic field, $\mathrm{W}$ - solar activity, $\mathrm{Kp}$ - geomagnetic disturbance.

tion index, while only in men the temperature index correlates positively with the intuitive thinking index $\mathrm{R}$ and negatively with the dual thinking index F. Intuitive thinking intensifies in harsh environmental conditions, which facilitate more successful adjustment. At the same time, intuitive thinking is considered the most ancient and probably responsible for higher aggression at 
temperatures above normal [9]. Apparently, temperature as a major factor in a study of 200 years of Russian poetry [23] is far from being a coincident.

The obtained data about variations in thinking types and their correlation with geocosmic conditions can be considered as manifestation of effects of weather and geocosmic fluctuations on growth and development rates of germinal layers and, particularly, of neurogenic ectoderm. The revealed differences in the dynamics of thinking indices in men and women in correlation with geocosmic parameters can be explained considering innate genetic differences of male and female bodies. Specifically, it has been shown that sperm cells have different electrochemical, physical and morphological characteristics depending on whether they are carrying an X- or an Y-chromosome set [5]; also, X-chromosomes are positively charged while Y-chromosomes carry negative electric charge [10].

\section{Creative musical thinking}

Content of 3352 Soviet songs and romances composed in 1935-1982 was analyzed. During the initial stage of the research, data about 2246 compositions was acquired via studying all Songs from Radio, Cinema and Television compilations (original title: „Pesni radio, kino i televidenia“) published monthly from 1959 to 1982 [20]. During the following stage of the research, information about 1106 Soviet songs composed in 1935-1958 was collected from the web sites http://sovmusic.ru, http://pesnifilm.ru and others. The results are shown in Fig. 5 and Table 1.

As can be seen in Fig. 5 and Table 1, there is evolution of music, largely dependent on geocosmic processes. In the whole studied period of 1935-1982 the major factors influencing optimism/pessimism index were earth's rotation

Table 1. Results of correlation analysis for songs in three periods of time

\begin{tabular}{|c|c|c|c|c|c|}
\hline \multicolumn{6}{|c|}{ Periods } \\
\hline \multicolumn{2}{|c|}{ 1935-1958 } & \multicolumn{2}{|c|}{ 1959-1982 } & \multicolumn{2}{|c|}{ 1935-1982 } \\
\hline Indices & Dur \% & Indices & Dur \% & Indices & Dur \% \\
\hline ERR & $0,616^{* * *}$ & ERR & $0,569^{* *}$ & ERR & $0,774^{* * * *}$ \\
\hline G & $-0,652^{* * *}$ & IMF & $0,699^{* * *}$ & IMF & $0,393^{*}$ \\
\hline$B C D$ & $-0,515^{* *}$ & G & $0,467^{*}$ & & \\
\hline
\end{tabular}

Keys: ${ }^{*}-p \leq 0.05 ;{ }^{* *}-p \leq 0.01 ;{ }^{* *}-p \leq 0.001$. Dur - share of songs in major, \%; ERR - Earth's rotation rate; IMF - interplanetary magnetic field; BCD - barycenter deviation; G - tidal power of Moon and Sun. 

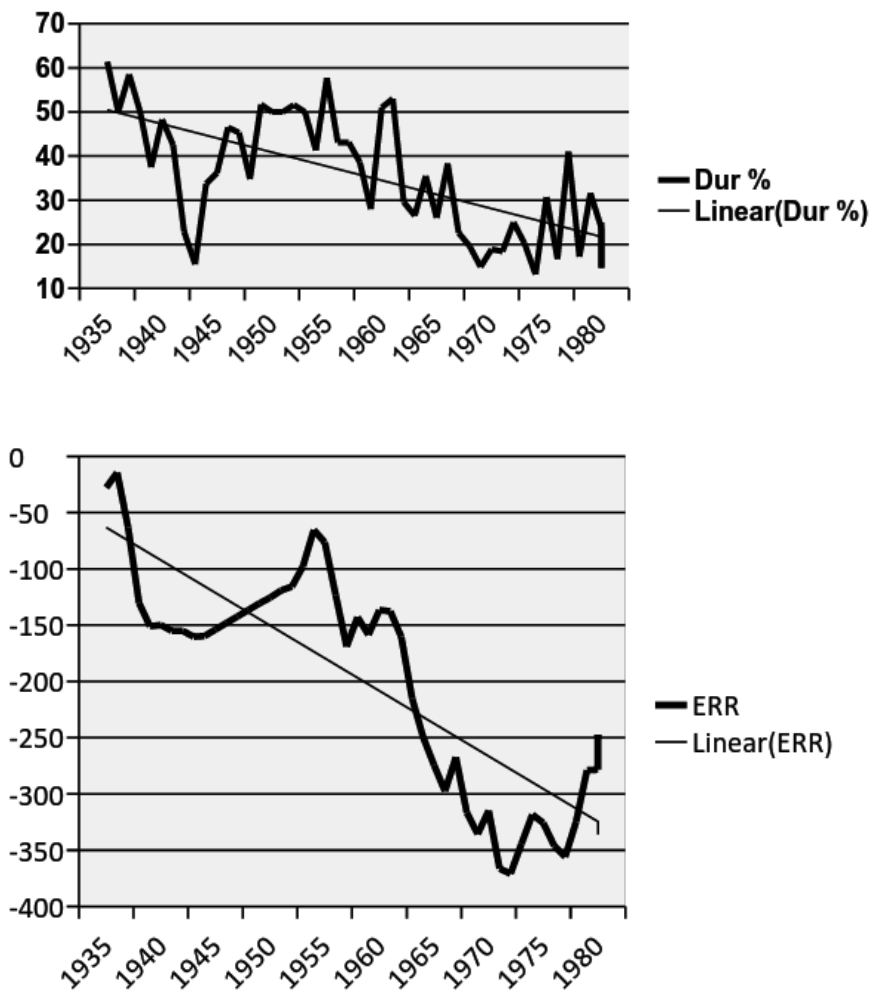

Figure 5. Correlation between share of songs in major Dur,\%, and Earth's rotation rate ERR; $r=0.774 ; p<0.0005$. Thin lines are for logarithmic trend.

rate ERR and interplanetary magnetic field IMF. During 1935-1958 optimism/ pessimism index was growing with the growth of ERR and decreasing with the growth of G and BCD indices. In 1959-1982 a positive correlation between Dur and IMF and a negative correlation between Dur and G were detected.

It is necessary to stress that oftentimes social processes can overweight and cancel the influence of cosmophysical factors. As an example, in the years of the WWII Dur index drops sharply, as well as total number of songs decreases drastically in the last years of the war and the early after-war years.

The presented results allow to state that geocosmic fluctuations affect coordination and alternate activation of brain hemispheres, and, consequently, dominant thinking type, which is reflected in social processes, including evolution of music. This is confirmed by modern scholars' conclusions $[6,12,13$, 
18, 19], particularly, by the thesis about fractal conjugation of human body and environment [18]. The discovered universal character of "macroscopic fluctuations" phenomenon in processes of any origin is caused by their fractality to Earth's motion in inhomogenous and nonisotropic time-and-space [12].

Undoubtedly, multicentury dynamics of cosmophysical processes put an immeasurably greater impact on humans and on sociohistorical processes.

\section{CONCLUSION}

There are daily, seasonal and multiyear variations in thinking parameters, largely determined by cosmophysical processes. Correlations between variations in thinking types, creative musical activity and geocosmic weather indices were discovered. The top influencing factors are Earth's rotation rate, interplanetary magnetic field and gravity.

Apparently, variability of natural processes determines variability of inherent thinking characteristics and creative activity and affects coordination and alternating activation of brain hemispheres. Thus, geocosmic processes to a large degree determine a dominant thinking type in a certain historical period. Such phenomena can be reflected in social processes, up to emerge of periods of so-called Thaw or Cold war.

\section{REFERENCES}

1. Chizhevskij A.L. (1924). Physical Factors in Historical Process [Fizicheskie faktory istoricheskogo protsessa]. Kaluga.

2. Danilova O.N., Petrov V.M. (1988). Periodical Processes in Musical Creative Activity [Periodicheskie protsessy v muzykalnom tvorchestve]. Priroda, 10, 54-59.

3. Haruto A.V., et al. (2007). Intensity of Russian Artistic Life: analysis of periodical components [Intensivnost' rossijskoj hudozhestvennoj zhizni: analiz periodicheskih komponent]. Sotsiologiya: metodologiya, metody, matematicheskoe modelirovanie, 25, 142-166.

4. Ishakov V.P. (1972). On Problem of Influence of Solar Activity onto Mental Illnesses [K probleme vliyaniya solnechnoj aktivnosti na psihicheskie zabolevaniya]. In: Solntse, elektrichestvo, zhizn'. Moscow, 70-71. 
5. Kaneko S., Iizuka R., Oshiro S., Nakajima H., Oshio S., Mohri H. (1983). Separation of Human X- and Y-Bearing Sperm Using Free-Flow Electrophoresis. Proc. Japan. Acad. 59, Ser. B, 8. https://doi.org/10.2183/pjab.59.276

6. Kaznacheev V.P., Trofimov A.V. (2004). Essays on Nature of Living Matter and Intellect on Planet Earth: Problems of Cosmoplanetary Anthropoecology [Ocherki o prirode zhivogo veschestva i intellekta na planete Zemlya: problemy kosmoplanetarnoj antropoekologii]. Novosibirsk: Nauka.

7. Makarova I.I. (2000). Influence of Geomagnetic Activity onto Interhemispheric Functional Brain Asymmetry [Vliyanie geomagnitnoj aktivnosti na mezhpolusharnuyu funktsional'nuyu asimmetriyu mozga]. Aviakosmicheskaya i ekologicheskaya meditsina, 34, 4, 50-54.

8. Maslov S.Yu. (1983). Asymmetry in Cognitive Mechanisms and Its Consequences [Asimmetriya poznavatel'nyh mehanizmov i eyo sledstviya]. Semiotika i Informatika, 20, 3-34.

9. Mayers D. (1999). Social Psychology [Sotsial'naya psihologiya]. SPb: Piter.

10. Nakata Y., Nakazawa T., Okuno M. (1989). Immunological Analysis on Surface, Properties of Human Spermatozoa. Zool Sci, 6, 6.

11. Petrov V.M., Mazhul' L.A. (1998). Cyclic Processes in Poetic Life of Russia in the $18-20^{\text {th }}$ centuries (quantitative aspect) [Tsiklicheskie protsessy v poeticheskoj zhizni Rossii XVIII-XX stoletij (kolichestvennyj aspekt)]. In: Informatsionnoe mirovozzrenie i estetika. Trudy mezhdunarodnogo nauchnogo simpoziuma. Taganrog: TRTU, 192-199.

12. Shnoll S.E. (2013). Fractality, "shoreline of the Universe", motion of the Earth and "macroscopic fluctuations" [Fraktal'nost', "beregovaya liniya Vselennoj", dvizhenie Zemli i "makroskopicheskie fluktuatsii”]. Biofizika, 58, 2, 357-376.

13. Sidorenkov N.S. (2001). The Physics of Non-stability in Earth's Motion [Fizika nestabil'nosti vrascheniya Zemli]. Moscow: RFFI, 377 p.

14. Sidorenkov N.S., Sumerova K.A. (2012). Geodynamical causes of decade variations in climate [Geodinamicheskie prichiny dekadnyh izmenenij klimata]. Gidrometeorologicheskie prognozy, 348, 195-214.

15. Sidorenkov N.S. (2015). On the Importance of Observations of Tidal Oscillation Effects on the Earth's Rotation Velocity [O vazhnosti nablyudenij za effektami prilivnyh kolebanij skorosti vrascheniya Zemli]. At: http://www.geoastro.ru/pdf/tidelnvz_rus.pdf

16. Sorokin P. (1937-1941). Social \& Cultural dynamics. New York: American Book C.

17. Torrance E.P. (1988). Style of Learning and Thinking. Administrator's Manual Published by Scholastic Testing Service, Inc. Bensenville.

18. Uritzkiy V.M., Muzalevskaya N.I. (1995). Fractal Structures and Processes in Biology [Fraktal'nye struktury i protsessy v biologii]. In: Biomeditsinskaya informatika i eniologiya. SPb: Izd. „Olga“, 84-129. 
19. Vladimirskij B.M. (2011). Kosmicheskaya pogoda - klimat i sotsialnye protsessy [Cosmic weather - climate and social processes]. Izvestiya Krymskoj Astrofizicheskoj Observatorii, 107, 189-209.

20. Volchek O.D. (2006) Geocosmos and humankind [Geokosmos i chelovek]. SPb: RGPU Publishing.

21. Volchek O.D., Pavlov K.L. (2012). Constitutional, Intellectual and Sensomotor Characteristics in relation to Natural Conditions of Early Embryogenesis and Onthogenesis [Osobennosti konstitutsii, intellekta i sensomotoriki v svyazi s prirodnymi usloviyami rannego embriogeneza i ontogeneza]. Aktual'nye voprosy antropologii, 7. Minsk: Belaruskaya nauka, 286-295.

22. Volchek O.D. (2013). Functional Brain Manifestations and Natural Environment [Funktzional'nye proyavleniya mozga i prirodnaya sreda obitaniya]. Aktual'nye voprosy antropologii. Sbornik nauchnyh trudov, 8. Minsk: Belorusskaya nauka, 66-76.

23. Volchek O.D. (2016). Creating Poetry in time Perspective. Papers on Anthropology, 25, 2, 98-112. https://doi.org/10.12697/poa.2016.25.2.10

\section{Address for correspondence:}

Olga D. Volchek

Ph.D. in Psychology, associate professor

Saint Petersburg, Kazanskaya, 45-81. 190000, Russia

E-mail: volchekod@mail.ru 